\title{
Creative Movement with Te and Ch'i - Global Virtual and Embodied Connection During the COVID-19 Pandemic
}

\section{贯穿 “德”与 “气” 的创意舞动 : 全球新冠疫情危机下的虚拟及具身化连接}

\author{
Marcia Plevin ${ }^{1}$ and Tony Yu Zhou ${ }^{2}$ \\ ${ }^{1}$ Association of Creative Movement, Italy \\ ${ }^{2}$ Inspirees Institute, China
}

\begin{abstract}
The COVID-19 epidemic, which emerged in China at the end of 2019, has quickly become a worldwide pandemic threatening the whole of humanity. The Chinese philosophy of Tao and Te, combined with the creative arts and specifically creative movement, highlight how embodied connection can be made through digital media to create a strong sense of belonging and emotional support. $C h$ ' $i$, the vital energy cultivated by virtue and good intention ( $T e)$, can lead to a positive and creative energy which creates synergy among people. This article describes, using concrete examples how a creative movement $(\mathrm{CM})$ session offered as part of an online webinar in March and April 2020 altered states of both mind and health. The webinars were initiated to encourage a global connection and to engender support within the professional community and were attended by both Chinese and overseas colleagues. Social responsibility, compassion, harmony with nature via Te and art-based practice are necessary to transform the current COVID-19 crisis into an opportunity and eventually a sustainable development for the world.
\end{abstract}

Keywords: arts therapy, $C h^{\prime} i$, Chinese philosophy, COVID-19, creative movement, online teaching, somatic education, $\mathrm{Te}$

\section{摘要}

新冠病毒疫情最早于2019年底在中国爆发，目前已经扩散到全世界，并成为威胁人类的 大规模流行病。国际艺术教育和治疗界对这一全球危机进行了回应。本文介绍了创意舞 动 ( 嘉力文技法 ${ }^{\circledR}$ ) 如何应用到2020年3月和2020年4月中外同行参加的全球网络分享会 中，并连接和支持到全球范围内专业社区的。本文着重探讨了中国哲学中的 “道 “和” 德“如何结合创造性艺术和过程，通过数字媒体建立具身化的体验和身心联系，以产生 强烈的归属感和情感支持的。“气” 是通过”德 “培育生发出来的重要能量，可以带来 正面积极的创造力，从而在人与人之间产生协同关系。文章呼唤新时代的领袖精神和社 会责任感，并通过 “德” 和基于艺术的实践与自然和谐相处，用慈悲心去应对当下的疫 情，将此次危机转化为机遇，并最终让全球获得可持续发展。

关键词 : 创意舞动，新冠疫情，在线教育，全球危机，中国哲学，德，气，艺术治疗，身心教育

\section{The coronavirus global crisis from the perspective of Chinese philosophy}

The outbreak of the coronavirus pandemic is having a huge worldwide impact on human beings. At this stage of the pandemic, China seems to have the COVID-19 virus under 
control, but in other parts of the world the virus is continuing to spread, noticeably in Europe, the United States and India causing a soaring death toll and consequently widespread anxiety and fear. It is still very uncertain how the pandemic will progress and affect the human species and society. During this pandemic, the novel coronavirus seems to be acting as a symbolic messenger warning human beings to pause and examine the way we interact with nature from different perspectives (Zhou, 2020). In the past hundreds of years, we have witnessed rapid development although it has not always been synchronized with the healthy advancement of humanity. National, regional, and global leadership is often widely questioned despite people's desperate need for it in the current global crisis. There have been always been different political, economic, cultural, and social approaches among countries when tackling crises in history such as WWI, WWII, the 1929 Great Depression to 9/11 and the 2008 financial crisis. One landmark for human evolution has been digital and online technology which has dramatically changed our sense of time and space, and consequently our sense of body, self, mind, and spirit. In this digital age, our life is accelerated in such a way that there is a huge gap between how we feel and live as an embodied and emotional person and the virtual world we are building. Digital media, together with other technologies already developed, hugely influence how we interpret the world, and the way we interact with the nature. We have seen nature being invaded by human beings disregarding the needs of other species with the assumption we can and are entitled to intervene and control nature largely with the assistance of technology. While technology is not meant to be the scapegoat, the intention, and the way we make use of technology is worth examining. It is interesting to realize that during and after the WWI and other global events, there was an influx of Western thinkers who traveled to China and Asia in search of spiritual inspiration, leadership, and possible solutions for the development of human society. Through thousands of years of history and civilization, China was able to offer ancient philosophy and wisdom to the world with mutual learning between East and West. One fundamental idea in ancient Chinese philosophy is the harmonious relationship with the nature which is essential to traditional Chinese culture and way of living. The relationship not only refers to having a respect for nature, but also to the appreciation of the authenticity of the nature from which the good intentions of a person arises. Such good intentions are related to Te (德), a key concept in Chinese philosophy and the classical text Tao Te Jing (道德经). Te is usually referred as "integrity" in Taoism, "virtue, morality" in Confucianism, and "quality, virtue" in Chinese Buddhism. The Chinese character of Te combines the 彳 (footstep; action) with 直 (straight; vertical) and 心 (heart; mind) (Figure 1). It also refers to the qualities of kindness, favor, grace, graciousness, and gratefulness in a person but extends to the universal love towards nature. The inherent qualities embedded in $T e$ are authenticity and naturalness of character, i.e., to follow nature and flow. $T e$, cannot be learned; it is innate, i.e., everyone is born with the sense of $T e$, so it is to be preserved from being lost in its purest and most natural form without any human intervention (wu-wei). Te is an open and neutral love and compassion without any preference. Te regards human beings as part of nature from which we gain resources, thus we are as equal as all other creatures in nature. 

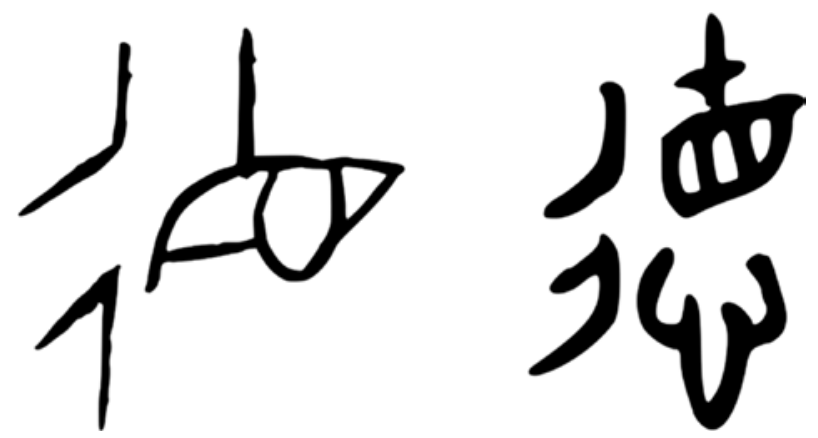

FIGURE 1 | Chinese Bronze script and Seal script for Te.

While $T e$ is not to be learned, it cultivates $C h^{\prime} i$ as it protects our natural actions and authentic expression. $C h$ ' $i$ is the vital force inside us and can exist or/and transform into creative energy and actions. It is consistently viewed as an empirical force and arguably does not carry the extensive religious attributions historically associated with the prevailing Western notion of a soul which is separate from the body (McNiff, 2016). Both $T e$ and $C h$ ' $i$ have a high regard for nature and encourage us to keep a harmonious relationship with our non-dualistic nature. They also exist in line with Tao where yinyang needs to be balanced. If there is balanced flow, for example, give and take in our actions, we are synchronized with Tao.

The COVID-19 crisis is an example of how the balance between human beings and other species in nature is disrupted. When looking at it, a suggestion would be to examine $T e$, i.e., do we have good intention to maintain our relationship with nature. It may be an appropriate time for us to bring Te back to our society and lives to cultivate compassion and unselfish love towards other species, and to bring the creative energy and flow to our modern culture. Yi (艺, the Chinese character for art), existing together with $T e$, is considered to find its way (Tao) in nature and is a highly regarded resource in Chinese and Eastern Asian philosophy (Kopytin et al. 2019). Unfortunately, nowadays with the advancement of technology, we seem to lose this balance and prioritize science and technology over arts. While we benefit from technology, we are experiencing the tightness and rigidity in our highly structured and organized society. Ironically, about 60 years ago Western students began going east to study Buddhism and meditation. In turn through Western transformation in the last 25 years the principles of Buddhism became a lay meditation practice without any religious overtones. Mindfulness, whose concepts and practices pervaded the Western world was then "imported" as a modern "technique" back into today's China where the body and mind are becoming more separated as in the West. Apparently, in both East and West we are alienating ourselves from nature instead of organically integrating ourselves as a part of nature.

The cultures of the world offer diverse body/mind/spiritual practices whose principles are in line with $T e$, raising $C h^{\prime} i$ and the concept of doing no harm. Creative Movement (the Garcia-Plevin ${ }^{\circledR}$ method) founded in Italy is one of these (Garcia et al, 2006). It aligns with the motivation and good intention to create and model a 
non-divisive, non-judgmental environment in its teachings. Through the art of nonjudgmental presence to one's body and mind it teaches how to access a consciously positive relationship to one's body. Through this creative process in movement can become more spontaneous and authentic. Art, music, dance and theatre all creative responses using the body have been origins of art in many cultures. What is the body if not nature embodied? Caring for oneself enables caring for others and then by extension to family, society, and the planet. Creating from the body's natural impulses (as a preliminary form of nature, without any intervention, i.e., wu-wei) during the creative process, comes through a practice of consciousness raising movement within Creative Movement training. What inhibits or stimulates one's own creativity: family, society, cultural customs? Essential to the training is learning the practice of Authentic Movement in order to align more deeply with $T e$ and Tao. It teaches a profound practice of bearing witness to one's inner self, to others and to the environment.

There is a need for humanity, solidarity, and leadership in the current global crisis. The re-integration of body-mind, the returning to nature is profoundly needed to restore the $T e$ and $C h{ }^{\prime} i$ for human beings. Without such a mission and vision, we will only perpetuate these crises and eventually undermine our own species in the universe.

\section{Creative Movement in action: global connection}

With the advancement of this global crisis, the arts education and therapy community in China and abroad began to respond both individually and collectively. In March 2020, the European faculty of Creative Movement (the Garcia-Plevin method) program ${ }^{1}$ offered an online creative movement (CM) session to support their Chinese students during their recovery from the coronavirus epidemic Within just a few weeks, the situation changed dramatically, with Europe and the US taking over as the world's epicenter for COVID-19. Then the Chinese community took the initiative to offer support to the world in return for their support to China in the previous months.

This collective initiative came from a good intention, in line with social responsibility and $T e$. It responded promptly to the emotional needs of people gaining momentum in our community. On April 5, 2020, a global webinar was organized by IACASE (International Association of Creative Arts Somatic Education) which gathered colleagues from 28 countries working in the field of Creative Arts Somatic Education $^{2}$. Artworks presentations, panel discussions, experiential movement sessions, and (sub-)group discussions were included in this global webinar. A strong response to creativity in movement, the visual arts and writing was experienced and observed during the online sessions. Technology was used to connect people virtually.

\footnotetext{
This training program began in Rome, Italy in 1993. Its main objective is to raise consciousness of body/mind/spirit unity through movement improvisation and art making, with contributions from theoretical research on the body practices and creativity, the languages of contemporary dance and the study and practice of mindfulness training.

2 Creative arts somatic education (CASE) refer to the body-mind integration with the creative use of arts. It covers different disciplines and practices including creative movement, dance therapy, etc.
} 
It all began with the question "what we can do for OTHERS?" - the right intention and positive energy $(\mathrm{Te})$ which inspired and guided us through the whole process.

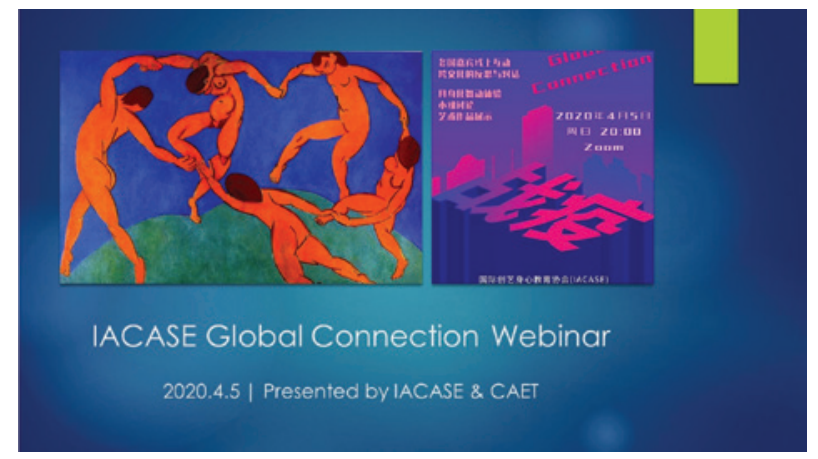

\section{Raising Ch'i through the screen}

Based on years of leading professional dance, dance therapy and choreography classes, I imagined that the antithesis of a shared physical moving space for embodied artistic expression would be a two-dimensional screen with myself on one side and a group of people on the other. Movement and visual or written arts expression where teacher and student are physically occupying the same room can become an alchemical vessel opening to individual and mutual creative expression. What I am naming as a "field of energy" can be drawn from and drawn out by the natural and vital movement quality of $C h{ }^{\prime} i$ in both myself and others. This vital natural energy source once found can be of service in any creative process.

Referencing the title of Shaun Mc Niff's article, “Ch' $i$ and artistic expression: an East Asian world view that fits the creative process everywhere" (McNiff, 2016), I have been challenged by the word "everywhere". In other words, where is this everywhere? Can $C h^{\prime} i$ be raised on one side of the screen in and between students on the other side? This Eastern concept of a universal energy source innate within and around the human body can be accessed and sourced by one's own receptivity in a non-judgmental environment. The attention and conditions needed to perceive this flow of energy is usually indicated, developed, and encouraged, initially, by the teacher.

A central question I had when thinking about leading a CM session online was; can my own $C h$ ' $i$ be invited, accessed, encouraged, drawn out and transmitted to the students, from my personal home space, through my body/voice and then through a digital medium? Will the students be able to develop their own learning energy field within their home space?

Two opportunities to spread CM globally using a digital medium presented themselves in quick succession, and both gave me a chance to experiment and respond to these questions. The first opportunity was a movement session for CM students and graduates of the Inspirees Institute, with the primary goal of connecting to and giving support for their creative resources in the time of confinement. The second, a few weeks, later was leading a CM session for a global digital conference for art educators 
and therapists who were invited as panelists to describe their own experience, of living with COVID-19. By the time of the conference the World Health Organization had changed the word epidemic to pandemic in defining the all-encompassing reach of this virus.

\section{First opportunity}

The CM students and graduates were meeting for the first time since the outbreak of COVID-19 in Wuhan, and were connected digitally from Shanghai, Beijing, Xian, and Changsha. Seated in front of my computer in Rovereto, Italy, I watched, feeling both amazement and joy as one by one they began appearing on the digital platform. Not speaking or understanding Chinese, I was drawn into witnessing the chatter and laughter from some and the wide eyed or vacant looks from others. As they recognized fellow class members, I had the sensation they were coming out of a cave into digital sunlight.

I found myself becoming embodied, the tingling of Ch'i rising just by witnessing their presence. Witnessing is a word that denotes more than looking or seeing; it is being present to perceptions and sensations within oneself while being present to the other (Adler, 2002). My cousin, Arlene Plevin, after reading this paper, noted it could be "an extension of human hunger, the hunger for presence". My physical, emotional, and mental perceptions were heightened. Frankly, I felt goosebumps, an instinctual response of the skin to emotional involvement. I was grateful to the digital medium for allowing a global lifeline for the group to meet. Witnessing a raised energy field within my body to be both alert and open to the newness of the situation, I began aligning intention, $T e$ and a body/mind presence $C h$ ' $i$ to the unusual (digital) situation at hand.

\section{The movement session}

Choices. I felt called to make a choice on how to guide and lead this exploration. Never having taught a digital movement class before, I allowed myself to be more directive than usual, but I also included free form improvisation.

Each participant was seated in front of their screen, seeing my body as well as those of the other participants in the class, listening to my voice directing the movement accompanied by music. The time and focus were directed towards the inner physical sensations of breath. I began to move; they began to move. I saw my movement mirrored in many different ways on the screen. A simultaneous "group flow" of movement began. I then encouraged them to let their breath increase the physical space in and around their body. This brought most people to their feet. As I observed the myriad of faces and bodies on the screen, I felt I was floating in space with my feet on the ground. Bodies began to fill the screen; rising, opening, and spreading. Eyes, heads, and arms moved more broadly around the space. They increasingly followed their own needs. Each participant improvised and explored how they experienced their internal and external space in the room.

There was no physical collective group space here. What I was seeing were many postage stamp heads or small bodies. I navigated, not by recognition, but by the 
movement or the colors of clothing flashing across my screen. Each person, in their own way, was breathing and moving through their internal and external space. I saw a face, a hand, a torso. Then I saw no one. Clear and simple verbal indications of what and how to move became essential. I trusted that. Perceptions of time accelerating, and space being altered by the screen were present. I was on my own, sensing and trusting my own energy field. That would be enough. Time for transitional creative art or writing was offered after the movement class, followed by small groups sharing their experiences in break out rooms on the digital platform. After that the larger group recomposed for collective sharing of the experience.

\section{What is the "takeaway" from the experience?}

From my perspective the participants' responses to the movement suggested that using this medium did allow for experimentation, creative processes and sharing. Did I sense an energy field of $C h{ }^{\prime} i$ had been manifested? I was able, at times, to catch expanded movement and transformation within the participants as I witnessed them embody their movement. There was, however, no qualitative measurements or gauge to know for sure, other than my own sensing of an energy field. Verbal sharing in the small and large groups brought out how the altered space during confinement shaped emotional responses to the virus. The entire experience was a personal creative process as I went in and out of being present in the teaching process. "Can a one-time, online creative movement process work"? It did do what it set out to do: create a space for a creative process for individuals with verbal group processing. Can it have a role in furthering experiential CM practice and experimentation in an ongoing group? Adapting to the different teaching and learning setting, to the altered sense of time and space on the screen, indicates that, yes, it can be used effectively.

\section{Second opportunity}

The global webinar was moderated by a Chinese and an American colleague. Our panelists were invited to share something of their experiences of the pandemic. This is a world-wide humanitarian crisis, reflecting the notion that sometimes human development occurred in a way that is without humanity.

The movement experiential I would be leading came after nine panelists from eight countries had spoken of their personal experience of COVID-19 to 78 participants. Each panelist brought visual art, words, poetry or music which attested to both the global suffering, but also to the light and healing that arts and therapy can bring to the despair and darkness. I sensed my role was to offer a unitive experience to a world collective body gathered online to bear witness to this historical time.

My reflections on the first opportunity gave me a road to follow. Out there... on the other side of the screen my body/ mind felt and knew there was an open world space that held a collective body. I could actually see at any one time 16 people on the screen. Two sources of information, one imaginal and other concrete, were present, allowing me to perceive, develop, and transmit $C h^{\prime} i$ in other words to set up an energy field first in myself. 
After an initial movement experience seated on a chair, the central part of the movement session was to stand up and sense their body verticality between heaven and earth. Many cultural traditions and world religions recognize the conduit humans hold as a channel between heaven and earth. Millions of people in the world were being affected by COVID-19. The hurt body needed to also become a source of healing.

I invited them to physically touch the center of their own body. From the center I named the north of the body, above the head, as the "north" of the world. Each person symbolically stood in the center of the world. I modeled the directions in arm and body movements from the center to the north, south, east and west, naming cities and countries in those directions from me which were caught in the pandemic net. The participants then experimented with these directions from the center of themselves opening their arms to the entire space around them, as part of the collective body. Wanting to leave the experience on a note where dance could offer a release from the tension they may have been feeling I chose rhythmic blues music which was upbeat, with quick accelerated accents. There was global dancing on the screen.

"When I closed my eyes and moved with the soft music and Marcia's gentle voice from the screen, I started to touch my own body with tenderness like a feather. It was the connection to myself, the inner vulnerable child who was longing for love and the connection to others. I was aware I was exposing myself to dozens of digital figures in front which gave me a momentary awkwardness. But the tenderness inside myself in its very natural and pure form became so powerful to enable me to get out of this discomfort to move into the group dance with other colleagues. Then all of sudden, the music and dance made me burst into tears and indulged myself in this soothing and loving moment. It was not solely the sympathy for the suffering of my human fellows in this pandemic, but the vivid energy I could feel alive inside of my body, the merge of Yin and Yang, and transformation from gentleness into strength as a living form in this universe, the connectedness to other bodies and souls sharing the collective experiences at that moment" (personal comment, T. Zhou)

After the movement experience, verbal sharing sessions in small groups gave participants a chance to express their feelings about the pandemic through what they had heard or what they had experienced through the movement. There was trust that the shared experience would allow for ways to communicate with each other.... a way was found. The larger group then convened, and a spokesperson offered the salient points of each group.

\section{The takeaways from this experience}

As strange as it seems I could sense an intimacy on the screen. I wanted to transmit from my own energy center a love and affection for the people I could and could not see, to enable through movement the sense that we are all one and in this together regardless of national boundaries or political positions. I discovered a deep connection 
can be forged through my own intention and trust. My personal presence was rooted in $T e$, a natural expression that could bring about the raising of Ch'i. Participants, on the other hand, had joined the conference to immerse themselves in a world response to the pandemic. I believe my intention coupled with their reason to be present in the conference enabled the movement session to become an interactive person to person flow across time and space. Flashes of movement seen as they danced around in their own homes, listening to the same music gave impetus and energy to their own dance. I offered movement stimulus and was gifted by their committed presence. Bringing the raising of $C h$ ' $i$ back into the picture as an underlying pervasive force in nature I would venture to say that there can be an energetic transmission through the screen. The dances danced all over the world were individual expressions of the soul. The $C h$ ' $i$ raised and felt within us integrated with the individual soul expression imbuing it to facilitate the creative process which seemed to nurture a virtual group. In my vision it is this preliminary energy which connects.

Joan Wittig, Vice President of IACASE, one of the moderators remarked, "We find, not surprisingly, that we share many common themes. We also find that our own ideas and themes are deepened and expanded as we come together. The small groups share their discoveries. In moving together, we have awakened some of our feeling experiences. The work shared and experienced today has been deeply, deeply moving. There has indeed been some transformation in each of us.

We have found that we are not just calming ourselves down, but we are diving in. In movement we have been given the opportunity to fly and to feel our feet on the earth. We have shared universal experiences and have remembered the importance of our real emotions including rage and trauma. We are feeling both connected and disconnected, and also the joy and pleasure of feeling a global connection. We find that the "screen" is a third object, and we explore what is lost and what is gained. The Internet is so unpredictable, our connection is unstable. Can you see me? Can you hear me? This is the perfect metaphor for our global experience.

We are wondering how we can help. Our internal witnesses have been activated, and we realize this is not a fight....it's not a fight. Most importantly, we know that we are the hope. In all of this, in the end, it's connection at the level of the people, it's us. We are the hope. We are the ones who will carry this forward, through this pandemic and into whatever is coming next. It's us, we, the people, who are going to carry this forward. Today is the beginning of that."

Feedback from members of the panel and participants ranged from being a positive unifying experience to joy and emotionally satisfying to feeling the power of one. Video clips were recorded of the conference https://vimeo.com/user109350435.

Online movement sessions, therapy and art therapies education, already a reality in the world, have been accelerated by the pandemic as social and work life switch 
to online platforms. A number of issues come up with using technological mediation (Malchiodi 2018; Sokolova 2019), that in the context of this article are too complex to be elaborated but important to mention. As Sokolova observes there are a collection of realities in bodily sensory dimensions that are present in front of and behind the screen. Ethical, confidentiality and security challenges are inherent in the use of the screen and need to be addressed in line with the population using them and goals set out for its use. Along with its capacity to connect us in the world it also needs to be used very consciously and wisely.

\section{On the edge of next evolution?}

COVID-19 has placed human beings on the edge of a next evolution. Will we be able to transform this pandemic from a crisis into an opportunity with the help of technology? Technology is developed by human beings. It is up to us how we are going to utilize it. Cynically or paradoxically, like the effect of the virus, technology and the Internet can divide human beings as well as unite them. Technology offers many possibilities, but it might also make us feel the power at hand, which can be played out as behaving more selfishly ... and act more individually and sometimes selfishly to influence the world and "control" our own life. While technology can be robust and powerful, it does not have a soul. The Internet can connect us as seen in the ability to dance together with others across the globe, but such technical connection alone does not make a direct link to nature, nor make us feel in resonance or in harmony with nature. $Y i$ (艺), art, as witnessed and bodily felt by the effect of CM in a virtual setting belongs to our natural resources that we can rely on, as well as other arts. The deep motivation and intention of the movement guide to transmit and raise $C h$ ' $i$ for creative expression was an act of integrating humanness with technology. Experiencing art through a digital medium is an organic link for human beings to nature and brings creative flow into our life. The successful global connection webinar by the international creative arts somatic community is a testimonial to how we can make good use of both our body and technology to raise $\mathrm{Ch}^{\prime} \mathrm{i}$ /creative energy from the right place synchronizing with $\mathrm{Te}$. At this critical period of global crisis, we are getting into a deeper recession and reflection. How will our bodies, minds and spirits develop in the future? It might be the time when human beings realize we are just one tiny part of nature and that we have a huge global responsibility to pollute or not to pollute her. Unfortunately, even with its roots in ancient philosophy, China failed to uphold the harmony between man and nature as the nation has produced environmental pollution due to its massive production in the global economy chain over the past decades. We all need to be called back to the body as a fundamental and creative source and to nurture the collaborations across the disciplines, nations, and species in a more balanced way. Zhuang $z i$ gives us a wake-up call to see the world from a wider perspective, not only the through the eyes of human species, in order to find the ultimate $T e$ and $T a o$ which exist at a more macro level integrating both dualities, yin-yang, art-science, body-mind, structure-creativity. This call can help us find authentic creative solutions and paths to a healthier humanity in the era....co-existing and beyond COIVD-19. 


\section{About the Authors}

Marcia Plevin's life has been dedicated to movement and dance, initially as a professional contemporary dancer, teacher, and choreographer. As a psychologist and artist she is now dedicated to bringing movement to everyone. She is a dance movement therapist (DMT), BC-DMT board certified by American Dance Therapy Association, is a teacher/supervisor for the DMT and CM program at the Inspirees Institute, Expressive Psychotherapy Institute Art Therapy Italiana, and is a co-founder of Creative Movement method Garcia-Plevin ${ }^{\circledR}$ training, she is on the faculty of the Circles of Four discipline of Authentic Movement training directed by J. Adler.

Tony Y. Zhou, PhD, is the Director of Inspirees Institute, China/Netherlands. He is also the founder and executive editor of Creative Arts in Education and Therapy (CAET). He trained as a biomedical scientist and later received training in dance/movement therapy and is the first certified movement analyst in mainland China. He cofounded the International Association of Creative Arts Somatic Education in 2019. He is the group leader of the Chinese Arts Therapy Committee under Chinese Psychological Society. ORCID:0000-0001-8099-6458.

\section{References}

Adler, J. (2002) Offering from a Conscious Body, the Discipline of Authentic Movement. Rochester, Inner Traditions.

Garcia M, Plevin, M, Macagno, P. (2006) Creative Movement and Dance. Rome: Gremese.

Kopytin, A., Bockhorni, R., Zhou, T.Y. (2019). From Ikebana to botanical arranging: Artistic, therapeutic, and spiritual alignment with nature. Creative Arts in Education and Therapy, 5(2): 96-108. DOI:10.15212/ CAET/2019/5/35

Malchiodi, C.A. (2018). Handbook of Art Therapy and Digital Technology. London: Jessica Kingsley.

McNiff, S. (2016). Ch'i and artistic expression: An East Asian worldview that fits creative process everywhere. Creative Arts in Education and therapy, 2 (2), 12-20.

Sokolova, E. (2019) The smartphone as witness: technological mediation of bodily sensory experience. Forum for Anthropology and Culture, no. 15 pp. 116-136. DOI: 10.31250/1815-8927-2019-15-15-116-136

Zhou, T.Y. (2020). Virus - On the edge of art and science, human beings, and nature. Creative Arts in Education and Therapy, 6 (1), 13-18. 